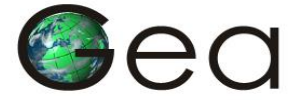

JURNAL PENDIDIKAN GEOGRAFI

\title{
PENGEMBANGAN DESAIN PEMBELAJARAN DENGAN MEMANFAATKAN KEBUN RAYA KUNINGAN SEBAGAI SUMBER BELAJAR
}

\author{
${ }^{1}$ Heru Nuryana, ${ }^{2}$ Epon Ningrum, ${ }^{3}$ Darsiharjo \\ ${ }^{1}$ SM AN 1 Pasawahan Kab. Kuningan-Jawa Barat, email: herunuryana@gmail.com \\ ${ }^{2}$ Jurusan Pendidikan Geografi, FPIPS UPI, email: epon.ningrum@y ahoo.com \\ ${ }^{3}$ Jurusan Pendidikan Geografi, FPIPS UPI, email: darsiharjo@y ahoo.com
}

\begin{abstract}
Learning source was a component which could not be separated from the learning achievement. Environment made up a component being able to be a learning source alternative. The existen ce of Kuningan Botanical Garden had a potency of being a learning source due to one its fo unding goals was to be a place of developing educational facilities to enhance social awareness and appreciation to the efforts of plant and environmental conservation. The research had purposes to analyze the potency, know the use, make a design of Geography learning, study the effectiveness of Kuningan Botanical Garden usage as a learning source of Geography through descriptive and ca se methods. The sample of research was Kuningan Botanical Garden, the students of class XI SMA Negeri 1 Pasawahan, and geography teachers. Data gathering technique used in the research was interview, test instrument, student's work sheet instrument, library study, and documentation. From the research, it was known that Kuningan Botanical Garden had a potency of being a learning source namely: environmental and human factors. The $45 \%$ of geography teachers used Kuningan Botanical Garden as a learning source. The researcher designed the learning by using the assignment method or recitation and field trip technique. The learning assessment result denoted that 83,9\% of students achieved the grade higher than minimum mastery criteria (KKM) so that Kuningan Botanical Garden was in the effective level of being a learning source.
\end{abstract}

Keywords: Learning design, learning, learning source.

\begin{abstract}
ABSTRAK
Sumber belajar merupakan kompenen yang tidak dapat dipisahkan dari tercapainya keberhasilan suatu pembelajaran. Lingkungan merupakan salah satu komponen yang dapat menjadi alternatif sebagai sumber belajar. Keberadaan Kebun Raya Kuningan memiliki potensi sebagai sumber belajar, karena salah satu tujuan dibangunnya Kebun Raya Kuningan adalah sebagai pengembangan fasilitas pendidikan untuk meningkatkan kepedulian dan apresiasi masyarakat terhadap upaya konservasi tumbuhan dan lingkungan. Penelitian ini bertujuan untuk menganalisis potensi, mengetahui pemanfaatan, membuat desain pembelajran geografi, dan mengkaji efektivitas pemanfaatan Kebun Raya Kuningan sebagai sumber belajar dalam pembelajaran geografi dengan menggunakan metode deskriptif dan metode kasus. Sampel dalam penelitian ini adalah Kebun Raya Kuningan, siswa kelas XI IPS 1 SMA negeri 1 Pasawahan, dan guru geografi. Teknik pengumpulan data dengan wawancara, instrumen tes, intrumen lembar kerja siswa (LKS), studi literatur, dan dokumentasi. Dari hasil penelitian diketahui Kebun Raya Kuningan memiliki potensi sebagai sumber belajar yaitu faktor lingkungan dan manusianya. Pemanfaatan Kebun Raya Kuningan sebagai sumber belajar masih rendah hanya $40,5 \%$ guru geografi sudah memanfaatkannya. Desain pembelajaran geografi yang dirancang yaitu menggunakan metode penugasan atau resitasi dengan teknik berkunjung (field trip). Dari hasil penilaian pembelajaran 83,9\% siswa memperoleh nilai di at as kriteria ketuntasan minimal (KKM), sehingga Kebun Raya Kuningan berada pada tingkat “efektif” sebagai sumber belajar.
\end{abstract}

Kata kunci: desain pembelajaran, pembelajaran, sumber belajar. 


\section{PENDAHULUAN}

Menurut Undang-Undang Sistem Pendidikan Nasional (UU SISDIKNAS) pasal 1 Tahun 2003 pendidikan memiliki arti:

"Usaha sadar dan terencana untuk mewujudkan suasana belajar dan proses pembelajaran agar peserta didik secara aktif mengembangkan potensi dirinya untuk memiliki kekuatan spiritual keagamaan, pengendalian diri, kepribadian, kecerdasan, akhlak mulia, serta keterampilan yang diperlukan dirinya, masyarakat, bangsa dan negara".

Peningkatan mutu pendidikan dapat kita lakukan dengan berbagai cara, salah satunya adalah dengan berusaha untuk memahami bagaimana peserta didik belajar dan bagaimana informasi yang diperoleh dapat di proses dalam pikiran mereka sehingga menjadi milik mereka serta bertahan lama dalam pikirannya. Oleh sebab itu, perlu diupayakan penerapan iklim belajar yang tepat untuk menciptakan lulusan yang benar-benar kreatif, inovatif dan berkeinginan untuk maju melalui pemanfaatan sumber belajar untuk mengembangkan potensiny a secara utuh dan optimal.

Geografi merupakan ilmu untuk menunjang kehidupan sepanjang hay at dan mendorong peningkatan kehidupan. Lingkup bidang kajiannya memungkinkan manusia memperoleh jawaban atas pertanyaan dunia sekelilingnya yang menekankan pada aspek spasial, dan ekologis dari eksistensi manusia. Bidang kajian geografi meliputi bumi, aspek, dan proses yang membentuknya, hubungan kausal dan spasial manusia dengan lingkungan, serta interaksi manusia dengan tempat.

Pembelajaran geografi di sekolah dianggap tidak menarik untuk dipelajari. Menurut Yani (2010: 9) ada beberapa faktor yang menyebabkan pembelajaran geografi tidak menarik antara lain karena: 1) Pelajaran geografi sering kali terjebak pada aspek kognitif tingkat rendah, y aitu menghapal nama-nama tempat, sungai dan gunung atau sejumlah fakta lainnya; 2) Ilmu geografi hanya menggambarkan tentang perjalanan-perjalanan manusia di permukaan bumi; 3) Proses pembelajaran ilmu geografi cenderung bersifat verbal, kurang melibatkan fakta-fakta aktual, tidak menggunakan media kongkrit dan teknologi mutakhir; dan 4) Kurang aplikabel dalam memecahkan masalah-masalah yang berkembang saat ini.

Salah satu permasalahan yang terjadi adalah keterbatasan kemampuan guru dalam memilih dan merancang sumber belajar yang kemudian diaktualisasikan dalam bentuk media dalam kegiatan pembelajaran. Menurut Association for Education and Communication Technology (1986: 89) sumber belajar adalah "sesuatu yang mendukung terjadinya proses belajar, termasuk sistem pelayanan, bahan pengajaran, dan lingkungan". Seiring dengan perubahan paradigma pendidikan dari "Teacher Center" ke "Student Center", maka fungsi guru juga berubah, tidak lagi sebagai pusat sumber belajar bagi siswa tapi lebih kearah sebagai fasilitator y ang memfasilitasi berbagai hal y ang diperlukan siswa untuk belajar.

Pemanfaatan lingkungan sebagai sumber belajar perlu mendapatkan perhatian lebih oleh guru dalam kegiatan pembelajaran. Menurut Rustaman (1996), banyak keuntungan yang akan kita peroleh jika kita menggunakan lingkungan sebagai sumber belajar, y aitu sebagai berikut: 1) Siswa mendapatkan informasi berdasarkan pengalaman langsung, karena itu pengajaran akan lebih bermakna dan menarik; 2) Pelajaran menjadi lebih kongkrit; 3) Penerapan ilmu dalam kehidupan sehari-hari menjadi lebih mudah dan sesuai dengan permasalahan yang dihadapi siswa; 4) Sesuai dengan prinsip-prinsip dalam pendidikan, yaitu belajar itu harus dimulai dari y ang kongkrit ke y ang abstrak, mudah/sederhana ke y ang sukar/kompleks, sudah diketahui ke yang belum diketahui; 5) Mengembangkan motivasi dan prinsip "belajar bagaimana belajar (learning how to learn)" berdasar kepada metode ilmiah dan pengembangan keterampilan proses sehingga akan tertanam sikap ilmiah; 6) Siswa dapat mengenal dan mencintai lingkungannya, sehingga akan timbul rasa syukur, mengagumi, dan mengagungkan kebesaran Tuhan Yang MahaEsa sebagai penciptanya. 
Penggunaan lingkungan sebagai sumber belajar dapat ditempuh dengan beberapa cara. Menurut Sudjana dan Rivai (2009: 209) ada beberapa cara memanfaatkan lingkungan sebagai sumber belajar, yaitu: 1) survey, 2) berkemah, 3) field trip atau karyawisata, 4) praktek lapangan, 5) proyek pelayanan dan pengabdian pada masyarakat, 6) mengundang nara sumber.

Keberadaan Kebun Raya Kuningan yang terletak di Desa Padabeunghar Kecamatan Pasawahan menyimpan potensi untuk dapat dijadikan sebagai salah satu sumber belajar dalam kegiatan pembelajaran. Tanaman koleksi merupakan kekayaan utama dan menjadi daya tarik tersendiri yang dapat digunakan menjadi sumber belajar dalam kegiatan pembelajaran. Untuk lebih jelasnya tentang lokasi Kebun Raya Kuningan dapat dilihat pada gambar 1 .

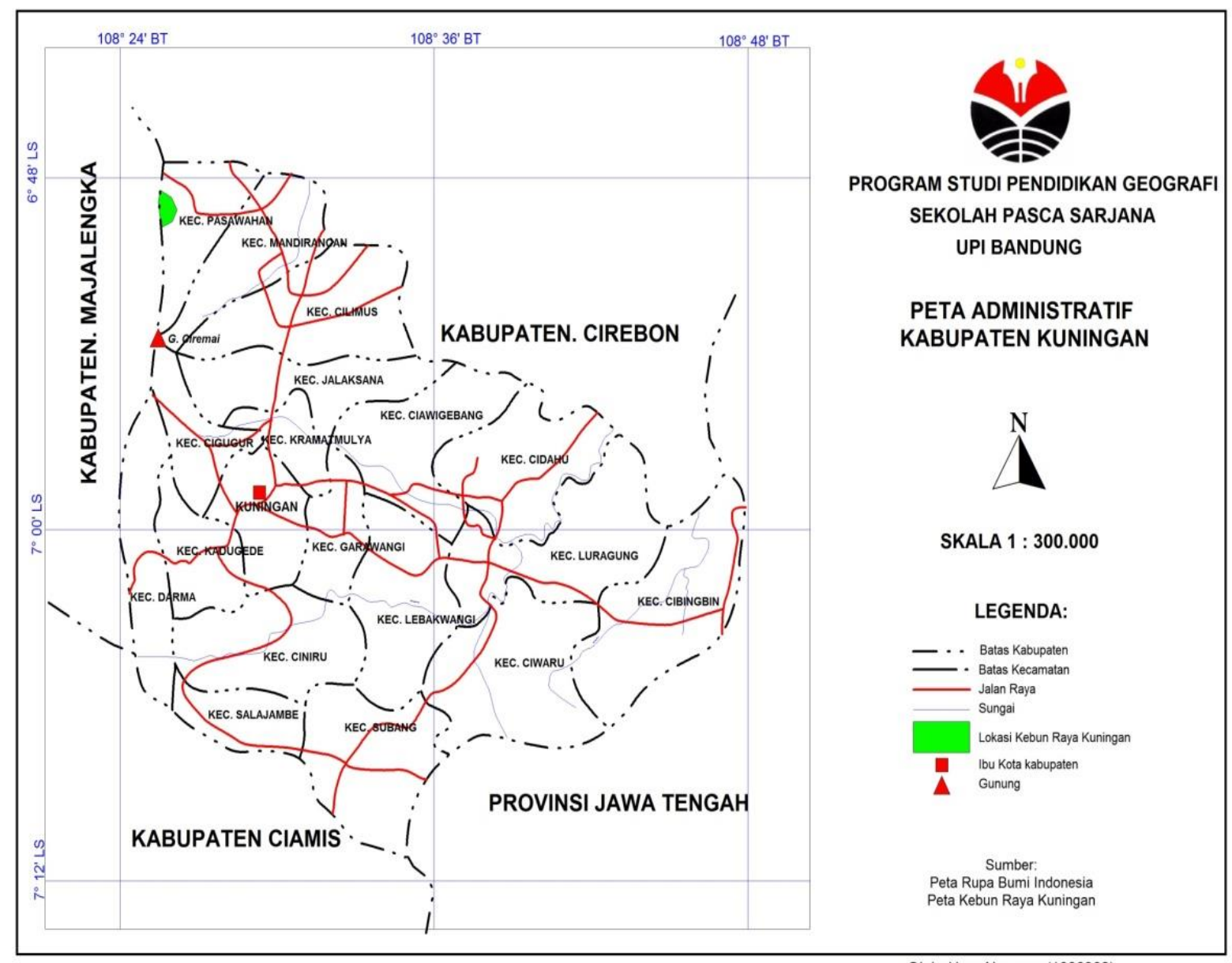

Oleh: Heru Nuryana (1006962)

Gambar 1. PetaLokasi Kebun Ray a Kuningan

Berdasarkan latar belakang di atas maka permasalahan penelitiannya adalah bagaimanakah pengembangan desain pembelajaran dalam pemanfaatan Kebun Raya Kuningan sebagai sumber belajar geografi, untuk menghindari penafsiran yang luas, maka dalam penelitian ini diarahkan untuk menjawab beberapa pertanyaan penelitian sebagai berikut: 1 Bagaimanakah potensi Kebun Raya Kuningan sebagai sumber belajar pada pembelajaran geografi? 2) Bagaimanakah pemanfaatan Kebun Raya Kuningan sebagai sumber belajar pada pembelajaran geografi? 3) Bagaimanakah desain pembelajaran geografi dalam memanfaatkan Kebun Raya Kuningan sebagai sumber belajar? 4) Bagaimanakah efektivitas Kebun Raya Kuningan sebagai sumber belajar pada pembelajaran geografi? 
Penelitian yang dilakukan ini dimaksudkan untuk pengembangan desain pembelajaran dalam memanfaatan Kebun Raya Kuningan sebagai sumber belajar geografi. Adapun tujuan penelitian ini adalah: 1) Menganalisis potensi Kebun Ray a Kuningan sebagai sumber belajar pada pembelajaran geografi; 2) Mengetahui pemanfaatan Kebun Raya Kuningan sebagai sumber belajar pada pembelajaran geografi; 3) Membuat desain pembelajaran geografi dalam memanfaatkan Kebun Ray a Kuningan sebagai sumber belajar pada pembelajaran geografi; 4) Mengkaji efektivitas pemanfaatan Kebun Raya Kuningan sebagai sumber belajar pada pembelajaran geografi.

Setelah mengkaji masalah yang ada, maka penulis menyimpulkan beberapa manfaat dari penelitian ini, yaitu: 1) Secara teoritis akademis, penelitian ini memberikan peluang bagi perluasan kajian akademik berkaitan dengan pengembangan desain pembelajaran pada pembelajaran geografi; 2) Secara praktis, dapat menjadi referensi yang dapat dipakai untuk pengembangan desain pembelajaran pada pelajaran geografi di tingkat SMA.

\section{METODE PENELITIAN}

Metode penelitian yang digunakan dalam penelitian ini adalah metode deskriptif dan metode kasus. Populasi dalam penelitian ini terdiri dari polpulasi wilayah dan populasi manusia. Populasi wilayah yaitu kawasan Kebun Raya Kuningan sedangkan populasi manusianya adalah seluruh staf dan pengelola Kebun Raya Kuningan, siswa kelas XI IPS di SMA Negeri 1 Pasawahan, dan guru geografi di Kabupaten Kuningan.

Sampel dalam penelitian ini terdiri dari sampek wilay ah dan sampel manusia. Sampel wilayah terdiri dari yaitu zona-zona Kebun Raya Kuningan yang memiliki karakteristik sumber belajar bagi pembelajran geografi yaitu: zona konservasi ex-situ koleksi Indonesia dan dunia, dan zona penelitian dan pendidikan. Sedangkan sampel manusia terdiri dari pengelola Kebun Raya Kuningan, siswa kelas XI IPS 1 di SM A Negeri 1 Pasawahan, guru geografi di Kabupaten Kuningan.

Metode pengumpulan data dalam penelitian ini terdiri dari enam cara: 1) wawancara, 2) angket/kuesioner, 3) instrumen tes, 4) instrumen lembar kerja siswa (LKS), 5) studi literatur, 6) dokumentasi. Instrumen dalam penelitian ini terdiri dari: lembar pedoman wawancara, angket/kuesioner, dokumentasi desain pembelajaran (silabus, desain pembelajaran, soal tes, lembar kerja siswa)

\section{HAS IL PENELITIAN DAN PEMBAHASAN}

Sumber belajar merupakan salah satu bagian y ang penting dalam keberhasilan kegiatan pembelajaran, karena dengan tersediany a sumber belajar yang baik akan mempermudah siswa dalam menyerap informasi tentang materi pembelajaran sehingga mampu menguasai kompetensi y ang diharapkan. Keberadaan Kebun Raya Kuningan sebagai suatu lingkungan y ang di desain untuk konservasi flora dan tujuan lainnya untuk sarana pendidikan sebagai sumber belajar.

Menurut Ningrum (2009: 109) jenis-jenis sumber belajar terdiri dari benda, karya ilmiah, manusia, dan lingkungan. Kebun Raya Kuningan memiliki potensi sebagai sumber belajar, komponen-komponen yang dapat dijadikan sumber belajar oleh siswa yaitu komponen lingkungan dan manusia. Komponen lingkungan yang dapat dijadika sebagai sumber belajar adalah tanaman koleksi yang berupa keanekaragaman tumbuhan. Komponen manusia yang terdiri dari pengelola dan petugas yang dapat dijadikan sebagai narasumber dalam kegiatan pembelajaran baik di dalam kelas (indoor) atau di luar kelas (outdoor).

Pemanfaatan lingkungan Kebun Raya Kuningan sebagai sumber belajar dalam kegiatan pembelajara masih kurang. Hal ini terlihat dari hasil angket yang dilakukan terhadap guru geografi se-Kabupaten Kuningan pada tabel di bawah ini: 
Tabel 1. Pemanfaatan Kebun Raya Kuningan sebagai Sumber Belajar

\begin{tabular}{cccc}
\hline No. & $\begin{array}{c}\text { Pemanfaatan } \\
\text { Kebun Raya Kuningan }\end{array}$ & Jumlah & Prosentasi (\%) \\
\hline 1. & Sudah memanfaatkan & 17 & 40,5 \\
\hline 2. & Belum memanfaatkan & 25 & 59,5 \\
\hline & Jumlah & $\mathbf{4 2}$ & $\mathbf{1 0 0}$ \\
\hline
\end{tabular}

Sumber: Hasil Penelitian 2012

Dari data pada tabel di atas 40,5\% guru sudah memanfaatkan Kebun Raya Kuningan sebagai sumber belajar dalam kegiatan pembelajarannya. Mereka dalam memanfaatkan Kebun Raya Kuningan sebagai sumber belajar dalam kegiatan pembelajaran meskipun dengan cara yang berbeda-beda, seperti: bercerita tentang Kebun Ray a Kuningan, berkunjung ke Kebun Raya Kuningan, dan dengan menggunakan media foto.

Sedangkan 59,5\% guru geografi di Kabupaten Kuningan belum memanfaatkan Kebun Raya Kuningan sebagai sumber belajar dalam kegiatan pembelajarannya. Kendala dan hambatan yang di hadapi guru berbeda-beda diantaranya: jaraknya jauh dari sekolah, kurangny a aksesibilitas, terkendala oleh keterbatasan waktu pembelajaran, dan kurang tahu informasi tentang keberadaan Kebun Raya Kuningan.

Penyusunan desain pembelajaran merupakan bagian yang penting, karena desain pembelajaran merupakan rancangan kegiatan pembelajaran yang akan dilakukan oleh guru. Sehingga dalam penyusunannya harus memperhatikan tahapan-tahapan yang harus dilalui. Penyusunan desain pembelajaran mengacu pada Model Inverted (Taba, 1962) yang terdiri dari beberapa tahapan, diantaranya: mendiagnosa kebutuhan siswa, merumuskan tujuan, memilih isi, mengorganisasi isi, memilih pengalaman belajar, mengorganisir pengalaman belajar, dan evaluasi pembelajaran.

Desain pembelajaran yang digunakan pembelajaran geografi dalam memanfaatkan Kebun Raya Kuningan sebagai sumber belajar memuat beberapa komponen diantaranya: materi pembelajaran, standar kompetensi, kompetensi dasar, indikator, tujuan pembelajaran, startegi/metode pembelajaran, langkah-langkah pembelajaran, media/alat bantu dan sumber, dan rancangan evaluasi.

Materi pembelajaran yang sesuai dengan pemanfaatan Kebun Raya Kuningan sebagai sumber belajar geografi adalah materi persebaran flora dan fauna. Standar kompetensi yang terkait dengan materi tersebut yaitu menganalisis fenomena biosfer dan antroposfer, sedangkan kompetensi dasar yang terkait dengan materi tersebut yaitu menganalisis sebaran tumbuhan dan hewan.

Rumusan indikator dalam pembelajaran geografi yang memanfatkan Kebun Raya Kuningan sebagai sumber belajar geografi adalah sebagai berikut: mengidentifikasi sebaran tumbuhan di permukaan bumi, menganalisis persebaran tumbuhan di Indonesia, menjelaskan hubungan sebaran tumbuhan dengan faktor-faktor y ang mempengaruhi sebaran mahluk hidup, mengidentifikasi upaya-upay a pelestarian flora serta damp akny a terhadap kehidupan.

Tujuan pembelajaran dalam desain pembelajaran yang memanfaatkan Kebun Raya Kuningan sebagai sumber belajar geografi adalah sebagai berikut: 1) setelah menyimak penjelasan guru siswa kelas XI IPS 1 mampu mengidentifikasi empat faktor yang berpengaruh terhadap persebaran mahluk hidup, 2) setelah menyimak penjelasan guru siswa kelas XI IPS 1 mampu menjelaskan hubungan persebaran flora dengan empat faktor yang mempengaruhi persebaran mahluk hidup, 3) setelah menyimak penjelasan guru siswa kelas XI IPS 1 mampu menjelaskan penyebab terjadinya perbedaan sebaran flora di dunia, 4) setelah menyimak penjelasan narasumber siswa kelas XI IPS 1 mampu mengidentifikasi sebaran flora di Indonesia, 5) setelah menyimak penjelasan narasumber siswa kelas XI IPS 
mampu mengidentifikasi tiga penyebab kerusakan flora, 6) setelah menyimak penjelasan narasumber siswa kelas XI IPS mampu menjelaskan tiga upaya penanggulangan kerusakan flora.

Metode pembelajaran yang digunakan dalam memanfaatkan Kebun Raya Kuningan sebagai sumber belajar dengan menggunakan metode penugasan atau resitasi. Guru memberikan penugasan kepada siswa untuk melakukan pengamatan sehingga siswa aktif dan belajar mengenai materi persebaran flora, dan juga siswa diberi tugas untuk mengisi lembar kerja siswa (LKS) selama melakukan kegiatan pembelajaran di Kebun Raya Kuningan.

Teknik pembelajaran yang digunakan dalam desain pembelajaran yaitu dengan mengajak siswa berkunjung (field trip) ke lokasi Kebun Raya Kuningan, dengan langkahlangkah kegiatan pembelajaran dibagi menjadi tiga tahapan, yaitu: kegiatan awal, kegiatan inti, dan kegiatan akhir.

Tahapan penyusunan desain pembelajaran yang terakhir adalah tahapan merancang evaluasi pembelajaran. Tujuan dari evaluasi pembelajaran adalah untuk mengukur tingkat penyerapan materi yang diberikan oleh guru, nara sumber, dan hasil pengamatan siswa selama melakukan kegiatan pembelajaran di Kebun Raya Kuningan. Rancangan evaluasi pembelajaran terdiri dari dua rancangan evaluasi, yaitu: evaluasi proses berupa instrumen lembar kerja siswa (LKS) dan evaluasi akhir berupa lembar tes pilihan ganda. Untuk lebih jelasnya mengenai langkah-langkah kegiatan pembelajaran di Kebun Raya Kuningan dapat dilihat pada tabel 2 . 
Tabel 2. Langkah-Langkah Kegiatan Pembelajaran

\begin{tabular}{|c|c|c|c|}
\hline No. & Tahap & Kegiatan Pembelajaran & Waktu \\
\hline \multirow{3}{*}{1.} & \multirow{3}{*}{$\begin{array}{l}\text { Kegiatan } \\
\text { Awal }\end{array}$} & Apersepsi: guru mengecek kesiapan siswa & \multirow{3}{*}{$\begin{array}{c}10 \\
\text { menit }\end{array}$} \\
\hline & & $\begin{array}{l}\text { Guru menanyakan kembali materi minggu lalu yang telah } \\
\text { diajarkan. }\end{array}$ & \\
\hline & & $\begin{array}{l}\text { Guru memotivasi siswa dengan cara menyampaikan tujuan } \\
\text { pembelajaran }\end{array}$ & \\
\hline \multirow{6}{*}{2.} & \multirow{6}{*}{ Kegiatan Inti } & Tahap Eksplorasi: & \\
\hline & & $\begin{array}{l}\text { - Guru memberikan informasi tentang persebaran flora } \\
\text { yang ada di dunia dan Indonesia, } \\
\text { - Guru membagi siswa kedalam } 5 \text { kelompok, masing- } \\
\text { masing kelompok mendapatkan Lembar Kerja Siswa } \\
\text { (LKS) }\end{array}$ & $\begin{array}{c}25 \\
\text { menit }\end{array}$ \\
\hline & & Tahap Elaborasi & \multirow{3}{*}{$\begin{array}{c}65 \\
\text { menit }\end{array}$} \\
\hline & & $\begin{array}{l}\text { - Masing-masing dari setiap kelompok mengisi Lembar } \\
\text { Kerja Siswa (LKS) sambil mendapatkan informasi dari } \\
\text { petugas Kebun Raya Kuningan tentang jenis-jenis flora, } \\
\text { asalnya, kerusakan, dan pemeliharaannya yang ada di } \\
\text { Kebun Raya Kuningan, kemudian }\end{array}$ & \\
\hline & & $\begin{array}{l}\text { - Petugas membawa siswa untuk berkeliling dan } \\
\text { menjelaskan koleksi yang dimiliki oleh Kebun Raya } \\
\text { Kuningan. }\end{array}$ & \\
\hline & & $\begin{array}{l}\text { Tahap Konfirmasi } \\
\text { - Guru memberikan kesempatan kepada salah satu } \\
\text { kelompok untuk menyampaikan hasil pengisisan } \\
\text { Lembar Kerja Siswa (LKS). } \\
\text { - Guru melakukan refleksi hasil kerja siswa }\end{array}$ & $\begin{array}{c}15 \\
\text { menit }\end{array}$ \\
\hline \multirow[t]{2}{*}{3.} & $\begin{array}{l}\text { Kegiatan } \\
\text { Akhir }\end{array}$ & $\begin{array}{l}\text { - Guru memberikan kesempatan kepada siswa untuk } \\
\text { bertanya apabila ada hal-hal yang kurang dimengerti. }\end{array}$ & \multirow[b]{2}{*}{$\begin{array}{l}20 \\
\text { menit }\end{array}$} \\
\hline & & $\begin{array}{l}\text { - Guru menyimpulkan materi yang sudah dipelajari } \\
\text { - Guru melakukan test terhadap hasil belajar siswa. } \\
\text { - Guru menginformasikan untuk materi minggu depan. } \\
\text { - Guru menutup kegiatan pembelajaran }\end{array}$ & \\
\hline
\end{tabular}

Sumber: Hasil Pengolahan 2012

Hasil penyusunan desain pembelajaran mengenai materi persebaran tumbuhan atau flora dipermukaan bumi yang memanfaatkan Kebun Raya Kuningan sebagai sumber belajarnya dengan menggunakan metode penugasan. Maka kegiatan pembelajaranny a dilakukan dengan cara membawa siswa berkunjung(field trip) ke Kebun Raya Kuningan.

Tahapan kegiatan pembelajaran yang dilakukan di Kebun Raya Kuningan dapat dilihat pada tahapan-tahapan sebagai berikut: 1) Setelah siswa datang dan berada di lokasi Kebun Raya Kuningan guru mengumpulkan siswa untuk memberikan pengarahan tentang kegiatan pembelajaran yang akan dilakukan selama berada di Kebun Raya Kuningan; 2) Kegiatan selanjutnya siswa dibawa berkeliling mengamati koleksi tanaman yang ada di Kebun Raya Kuningan dengan bantuan petugas sebagai narasumber untuk menjelaskan berbagai macam koleksi y ang ada di Kebun Raya Kuningan. Lokasi pertama yang dituju oleh siswa adalah area atau zone konservasi ex-situ koleksi Indonesia dan dunia, selama di area ini siswa dapat melakukan kegiatan pembelajaran sebagai berikut: a) siswa dapat mengamati koleksi tanaman ex-situ yang bersal dari berbagai daerah di Indonesia; b) siswa dapat mengamati koleksi tanaman ex-situ yang berasal dari negara lain; dan c) siswa dapat menganalisis perbedaanperbedaan tanaman yang ada di Indonesia atau yang berasal dari negara lain. Lokasi kedua yang dituju oleh siswa adalah area atau zone pendidikan dan penelitian, kegiatan pembelajaran sebagai berikut: a) siswa dapat melihat bagaimana cara melakukan penyemaian 
benih tanaman; dan b) siswa dapat melihat kegiatan dari mulai penyemaian benih, pembesaran, sampai proses penanaman benih; 3) Setelah selesai melakukan kegiatan observasi, kemudian siswa berkumpul kembali ditempat awal untuk melakukan kegiatan inti y aitu tahap konfirmasi. Kemudian kegiatan akhir dengan melakukan kegiatan evaluasi berupa tes kepada peserta didik.

Efektivitas pembelajaran yang memanfaatkan Kebun Raya Kuningan sebagai sumber belajar dapat diketahui dari dua indikator, yaitu dari hasil penilaian tes dan penilaian lembar kerja siswa (LKS). Tingkat efektifitas pembelajaran dan asil penilaian akhir (penilaian tes dan lembar kerja siswa) dapat dilihat pada tabel 3 dan 4.

Tabel 3. Tingkat Efektifitas Pembelajaran

\begin{tabular}{ccc}
\hline No. & $\begin{array}{c}\text { Prosentase Siswa yang } \\
\text { Memenuhi KKM }\end{array}$ & Tingakt Efektifitas \\
\hline 1 & $75-100 \%$ & Efektif \\
\hline 2 & $50-74 \%$ & Sedang \\
\hline 3 & $25-59 \%$ & Kurang \\
\hline 4 & $\leq 24 \%$ & Tidak Efektif \\
\hline
\end{tabular}

Tabel 4. Hasil Penilaian Akhir Siswa Kelas XI IPS 1

\begin{tabular}{|c|c|c|c|c|c|c|}
\hline No & NAMA & $\begin{array}{c}\text { NILAI } \\
\text { TES }\end{array}$ & $\begin{array}{c}\text { NILAI } \\
\text { LKS }\end{array}$ & $\begin{array}{r}\text { NILAI } \\
\text { AKHIR } \\
\end{array}$ & KKM & KETERANGAN \\
\hline 1 & Agus Mihidin & 67 & 76,5 & 73,3 & 75 & Tdk Lulus \\
\hline 2 & Angga zulfikar & 73 & 82,4 & 79,3 & 75 & Lulus \\
\hline 3 & Anggi Permana & 93 & 88,2 & 89,8 & 75 & Lulus \\
\hline 4 & Aris Wibisana & 73 & 82,4 & 79,3 & 75 & Lulus \\
\hline 5 & Avinda deviana & 93 & 76,5 & 82,0 & 75 & Lulus \\
\hline 6 & Azis Sugianto & 80 & 76,5 & 77,7 & 75 & Lulus \\
\hline 7 & Dede Permadi & 67 & 82,4 & 77,3 & 75 & Lulus \\
\hline 8 & Dini Haryani & 87 & 88,2 & 87,8 & 75 & Lulus \\
\hline 9 & Eeji Nurlaji & 67 & 82,4 & 77,3 & 75 & Lulus \\
\hline 10 & Enjen Sujana & 80 & 76,5 & 77,7 & 75 & Lulus \\
\hline 11 & Feri Saputra & 67 & 76,5 & 73,3 & 75 & Tdk Lulus \\
\hline 12 & Fini Apriani & 87 & 82,4 & 83,9 & 75 & Lulus \\
\hline 13 & Iin Indrayani & 93 & 88,2 & 89,3 & 75 & Lulus \\
\hline 14 & Kurnia Sandy & 73 & 82,4 & 79,3 & 75 & Lulus \\
\hline 15 & Lisa Andriyani & 87 & 76,5 & 80,0 & 75 & Lulus \\
\hline 16 & M.Sarupiddin & 67 & 76,5 & 73,3 & 75 & Tdk Lulus \\
\hline 17 & Mus'ab & 87 & 82,4 & 83,9 & 75 & Lulus \\
\hline 18 & Regi Eryana & 80 & 88,2 & 85,5 & 75 & Lulus \\
\hline 19 & Resty Titis. P & 93 & 82,4 & 85,9 & 75 & Lulus \\
\hline 20 & Rian Dwi Y & 60 & 76,5 & 71,0 & 75 & Tdk Lulus \\
\hline 21 & Rizki Suryadinata & 80 & 76,5 & 77,7 & 75 & Lulus \\
\hline 22 & Rosnipah & 80 & 82,4 & 81,6 & 75 & Lulus \\
\hline 23 & Sandi Indra P. & 67 & 88,2 & 81,1 & 75 & Lulus \\
\hline 24 & Siti Nurjanah & 87 & 82,4 & 83,9 & 75 & Lulus \\
\hline 25 & Suci Hati & 80 & 76,5 & 77,7 & 75 & Lulus \\
\hline 26 & Tina Septiani & 87 & 76,5 & 80,0 & 75 & Lulus \\
\hline
\end{tabular}




\begin{tabular}{lllllll}
27 & Tuti Susilawati & 80 & 82,4 & 81,6 & 75 & Lulus \\
\hline 28 & Umay Umayah & 60 & 88,2 & 78,8 & 75 & Lulus \\
\hline 29 & Yovie Widianto & 80 & 82,4 & 81,6 & 75 & Lulus \\
\hline 30 & Yunus Abdulah & 60 & 76,5 & 71,0 & 75 & Tdk Lulus \\
\hline 31 & Yusuf Ibrahim & 73 & 76,5 & 75,3 & 75 & Lulus
\end{tabular}

Sumber: Hasil Penelitian 2012

Dari hasil data di atas menunjukan $83,9 \%$ siswa memperoleh nilai di atas kriteria ketuntasan minimal (KKM), sedangkan 16,1\% memperoleh nilai di bawah kriteria ketuntasan minimal (KKM). Dilihat dari tingkat efektifitas, pemanfaatan Kebun Ray a Kuningan "efektif" sebagai sumber belajar dalam kegiatan pembelajaran yang sesuai dengan tahapan-tahapan y ang direncanakan.

\section{S IMPULAN}

Kesimpulan hasil penelitian yang didapatkan sebagai berikut: 1) Berdasarkan pengamatan di lapangan Kebun Raya Kuningan memiliki potensi untuk dijadikan sebagai sumber belajar. Potensi tersebut terletak pada aspek lingkungan dan manusia. Sedangkan aspek benda dan karya ilmiah yang dapat dijadikan sebagai sumber belajar masih kurang; 2) Pemanfaatan Kebun Raya Kuningan sebagai sumber belajar dalam kegiatan pembelajaran masih sangat kurang. Dari data yang diperoleh hanya 40,5\% guru geografi sudah memanfaatkan Kebun Raya Kuningan sebagai sumber belajar, sedangkan 59,5\% guru geografi belum memanfaatkan Kebun Raya Kuningan sebagai sumber belajar dalam kegiatan pembelajarannya; 3) Penyusunan desain pembelajaran terdiri dari beberapa tahapan, diantaranya: mendiagnosa kebutuhan siswa, merumuskan tujuan, memilih isi, mengorganisasi isi, memilih pengalaman belajar, mengorganisir pengalaman belajar, dan evaluasi pembelajaran; 4) Hasil penilaian akhir siswa (penilaian tes dan lembar kerja siswa) menunjukan bahwa $83,9 \%$ siswa memperoleh nilai di atas kriteria ketuntasan minimal (KKM), sedangkan 16,1\% memperoleh nilai di bawah kriteria ketuntasan minimal (KKM). Dilihat dari tingkat efektifitas pembelajaran, pemanfaatan Kebun Raya Kuningan berada pada tingkat "efektif" sebagai sumber belajar dalam kegiatan pembelajaran yang sesuai dengan y ang direncanakan.

Adapun rekomendasiny a yaitu 1) Keberadaan sumber belajar yang berupa benda dan karya ilmiah di Kebun Ray a Kuningan harus diperbany ak, sehingga beberapa tahun kedepan Kebun Raya Kuningan dapat dijadikan sebagai sumber belajar y ang lengkap mulai dari aspek lingkungan, manusia, benda, dan karya ilmiah; 2) Perlu adany a sosialisasi y ang luas, baik ke masyarakat umum atau dunia pendidikan tentang keberadaan Kebun Ray a Kuningan sehingga masyarakat atau dunia pendidikan dapat memanfaatkan keberadaan Kebun Raya Kuningan sesuai fungsinya; 3) Guru khususny a guru geografi harus pandai-pandai memilah dan memilih sumber belajar y ang tepat dalam kegiatan pembelajarannya. Penggunaan lingkungan yang ada di sekolah atau lingkungan di luar sekolah sebagai sumber belajar merupakan salah satu alternatif y ang dapat dipilih.

\section{DAFTAR PUS TAKA}

AECT. (1986). Definisi Teknologi Pendidikan. Jakarta: PAU-UT dan CV. Rajawali Ningrum, E. (2009). Kompetensi Profesional Guru dalam Konteks Strategi Pembelajaran. Bandung: Buana Nusantara

Rustaman, A. (1996). Pemanfaatan Lingkungan sebagai Sumber Belajar IPA. Jakarta: Balitbang Dikbud

Sudjana dan Rivai. (2009). Media Pengajaran. Bandung: Sinar Baru Algensindo 
Taba, H. (1962). Curriculum Development (theory and practice). New York : Harcourt, Brace $\&$ world, Inc Atlanta.

Undang-Undang Sistem Pendidikan Nasional Tahun 2003.

Yani, A. (2010). Pengembangan Model Meaningful Learning Untuk Meningkatkan Daya Nalar Siswa Melalui Aplikasi Mindmap Pada Mata Pelajaran Geografi di SMA. Disertasi SPs UPI, Bandung: tidak diterbitkan. 